Article

\title{
Water Environmental Functional Zoning at County Level and Environmental Contamination Carrying Capacity Accounting in the Mainstream of Xiaofu River
}

\author{
Shaoxuan Ding ${ }^{1}$, Fangshun Wang ${ }^{2}$, Xining Sun ${ }^{3}$, Jincheng Ding ${ }^{4, *}$ and Jie Lu ${ }^{4, *}$ \\ 1 Faculty of Science, University of Melbourne, Parkville, Victoria 3010, Australia; \\ shaoxuand@student.unimelb.edu.au \\ 2 Boshan District Ecological Environmental Technology Service Centre, Zibo 255200, China; wfs5513@126.com \\ 3 Shandong Service Centre of Environment Assessment on Construction Project, Jinan 250000, China; \\ sunyixin21999@163.com \\ 4 School of Chemistry and Chemical Engineering, Shandong University of Technology, Zibo 255000, China \\ * Correspondence: djclj@126.com (J.D.); lujied@126.com (J.L.); Tel.: +86-533-2783397 (J.D.)
}

check for

updates

Citation: Ding, S.; Wang, F.; Sun, X.;

Ding, J.; Lu, J. Water Environmental Functional Zoning at County Level and Environmental Contamination Carrying Capacity Accounting in the Mainstream of Xiaofu River. Water 2022, 14, 615. https://doi.org/ 10.3390/w14040615

Academic Editor: Stefano Amalfitano

Received: 9 December 2021 Accepted: 14 February 2022 Published: 17 February 2022

Publisher's Note: MDPI stays neutral with regard to jurisdictional claims in published maps and institutional affiliations.

Copyright: (c) 2022 by the authors. Licensee MDPI, Basel, Switzerland. This article is an open access article distributed under the terms and conditions of the Creative Commons Attribution (CC BY) license (https:/ / creativecommons.org/licenses/by/ $4.0 /)$.

\begin{abstract}
Water environmental functional zoning is the crucial method to implement the targeted management of environmental factors, which is significant to protect the structure and function of the water ecosystem. Xiaofu River is the main river in Zibo City, which is a typical industrial city in northern China. This paper analyzes the water functional zoning of the Xiaofu River at the provincial and municipal levels. Thereinto, based on the catchment attribute and differentiated management requirement, the functional zone of the mainstream of Xiaofu River is divided into 5 first-level and 14 s-level water functional zones, where the environmental contamination carrying capacity of every functional zone is calculated and checked. It is suggested that the total amount of pollutants discharged into each functional zones should be further controlled and reduced in the future to restore the ecological functions of Xiaofu River.
\end{abstract}

Keywords: water environmental functional zoning; functional zones; first-level water functional zones; second-level water functional zones; environmental contamination carrying capacity

\section{Introduction}

Environmental functional zoning refers to the spatial and temporal division or classification of environmental elements according to the different functional requirements; it also can be regarded as an effective tool for designing and implementing differentiated environmental management policies in various designated regions [1,2]. In the early 19 th century, environmental functional zoning was developed from the regionalization theory. As the Merriam ecological zoning scheme was constructed and spread, the distinguishment and concept of ecological zones became definite and clear [3,4]. In the mid of 1980s, the United States Environmental Protection Agency (EPA) proposed freshwater ecological zoning to protect hydrochemistry and control water pollution, which consequently and effectively protects the structure and function of the entire water ecosystem [5]. Under the guidance of the national main functional zoning, regional environmental functional zoning requires comprehensively considering the inference and impacts of the regional economy and social activities on the local environment [6]. Furthermore, environmental functional zoning is supposed to analyze and determine the environmental functions (e.g., drinking water resources, industrial water use, agricultural water use, landscape water use, fishery water) of different regions with the consideration of society, economy and environment, and on the basis of that, the overall planning of environmental spatial zoning management is achieved [7]. The implementation of environmental functional zoning is also beneficial for the construction of a regional environmental management framework that is divided into four steps: the first step is data collection and analysis [8], the second is the evaluation 
of environmental function, the third procedure is environmental functional zoning, and the last one is about the formulation of environmental controlling objectives and environmental management measures [9]. Therefore, based on the natural conditions, the current developing situation of water resources, the comprehensive catchment program, the requirements of water source protection, and economic and social development demand, both the water differentiated zoning range and the relevant water environmental quality standard are determined [10]. Additionally, its dominant function has great significance of preventing water pollution and protecting water resources and water ecology [11]. Logical and equitable water environmental functional zoning also contributes to agro-ecological zoning (AEZ), thus promoting the rational allocation and adequate utilization of water resources so that they can be used in the best and most profitable productivity [12].

As Zibo is a typical industrial city in northern China, its water environmental functional zoning is particularly important in urban planning and has great impacts on environment protection. At present, the water function division covers almost all the major rivers, lakes, reservoirs, and other surface water bodies in China. First-level zoning is based on a watershed, which provides a scientific basis for watershed management [13]. The second-level division is mainly divided by provinces (autonomous regions and municipalities directly under the Central Government), which has laid a good foundation for the regional management of water resources [14]. Municipal water functional zoning is determined on the basis of the water functional zoning plan promulgated by the Shandong provincial government to delimit the municipal water functional zoning of rivers. This regionalization combines with the local actual and current functional situation, as well as according to the national standard Water Functional Zone Division Standard (GB/T 50594-2010). With the establishment of the water functional zoning system at provincial and municipal levels and the implementation of the river-lake chief system in China [15], it is necessary to refine the functional zones of main rivers, lakes, reservoirs at the district and county level and assess the environmental carrying capacity of each functional zone with reducing the number of pollutants discharged into the river, due to their basin attribute and differentiated management requirements [16]. Therefore, the differentiated management works of county-level water pollution control and water resource conservation are allocated. Currently, with the social economy continuous development and the change in water environmental protection situation, it is essential to ensure the dominant environmental functions of each county-level water area and improve the water environmental functional zoning system. Additionally, these two measures have become the necessary demand for solving ecological water problems and optimizing economic development.

\section{Materials and Methods}

\subsection{Study Area: Xiaofu River System Profile}

Xiaofu River is one of the main rivers running through the south to the north in Zibo, a typical northern city in China. Xiaofu River is a first-level tributary river on the right bank of Xiaoqing River; the total area of the catchment is $1733 \mathrm{~km}^{2}$, where the basin area within Zibo accounting for $83.2 \%$ is $1441.8 \mathrm{~km}^{2}$ [17]. Xiaofu River flows through five districts in Zibo city, all of which are economically developed areas. Therefore, the water functional zoning and managed protection of these five developed districts have significant impacts on promoting local ecological construction.

Xiaofu River originates in Yueyang mountain, Qingshi strategic pass, and Yuwang mountain area. It starts at Shentou spring groups in Boshan district and then flows northwards to Yuan bridge in Zhoucun district [18]. The total length of the Xiaofu River is $135.9 \mathrm{~km}$, where the trunk stream is $112 \mathrm{~km}$, the length of river running in Zibo is $109 \mathrm{~km}$, and the length of the main stream is $85.7 \mathrm{~km}$ [19]. In addition, the width of the trunk stream of Xiaofu River approximately is 20-100 m, and Xiaofu River has several tributaries, for instance, Fanyang River, Shigou River, Gan River are on the left bank, and Boyang River, Mansi River, Zhulong West River are on the right bank [20]. The location of Xiaofu River in Shandong province and Zibo city is shown in Figure 1. 


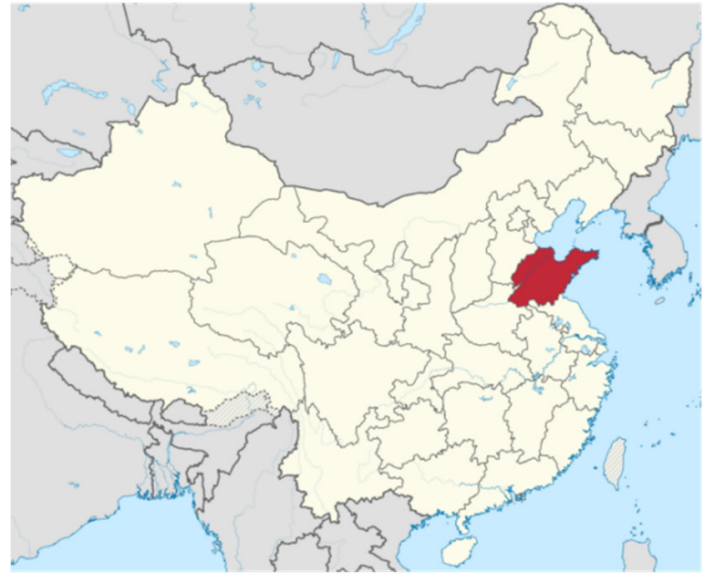

(a)

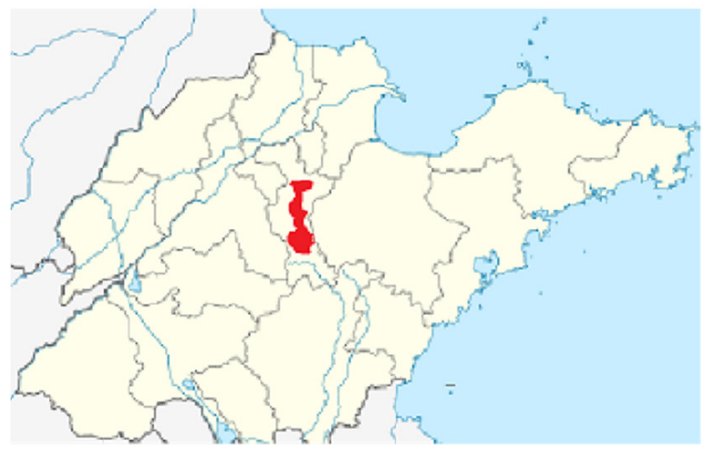

(b)

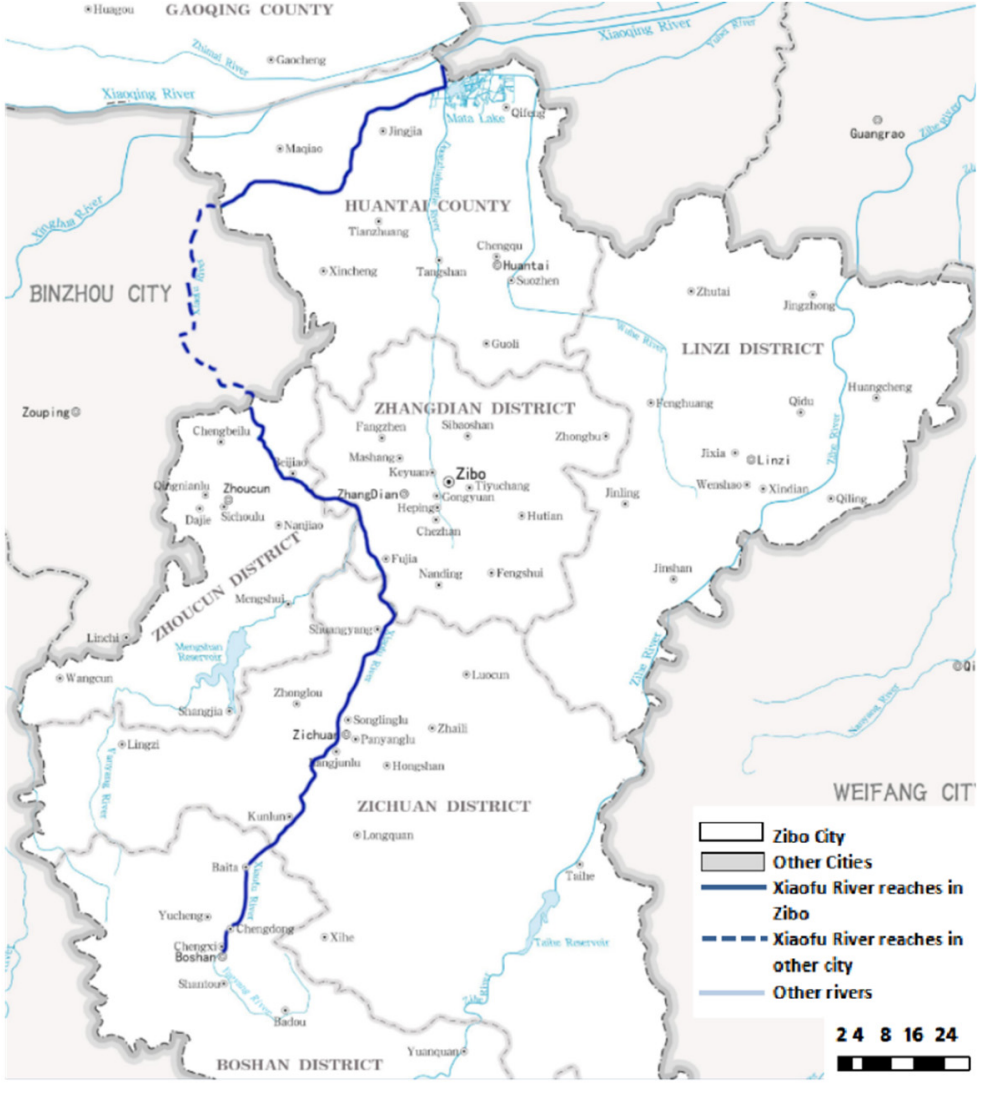

(c)

Figure 1. (a) Location of study area in China (b) Location of Xiaofu River basin in Shandong province (c) Xiaofu River basin in Zibo city [20].

\subsection{Water Quality Data and Evaluation}

\subsubsection{Water Sampling and Analysis}

Six water quality sampling sections were set up in the main stream of Xiaofu River, and sampling and water quality testing were performed according to the Technical Specification for Monitoring Surface Water and Wastewater (HJ/T 91-2002).

\subsubsection{Evaluation Criterion}

Environmental Quality Standards for Surface Water (GB3838-2002) were adopted, both basic parameters and supplement parameters by water source area are shown in Table 1.

\subsubsection{Evaluation Methodology}

The single index evaluation method was employed to select the two most important water quality indexes, $\mathrm{COD}$ and $\mathrm{NH}_{3}-\mathrm{N}$, as representative factors to separately determine the water quality classification of each individual water quality index [21], and the worst result was taken as the overall water quality classification. Furthermore, those indexes with water quality exceeding the class III standard limiting value in GB3838-2002 could be considered as exceeding indexes, and the excess multiple of these items can be calculated by following Formula (1):

$$
\mathrm{B}_{i}=\frac{C_{i}}{S_{i}}
$$

where $\mathrm{B}_{i}$ is the excess multiple of exceeding items in water functional zones, $C_{i}$ is the concentration of water quality indexes in water functional zones; $S_{i}$ is the standard limiting values corresponding to water quality management objectives in water functional zones (mg/L). 
Table 1. Environmental Quality Standards Parameters for Surface Water (GB3838-2002) Unit: mg/L.

\begin{tabular}{|c|c|c|c|c|c|c|}
\hline \multicolumn{2}{|c|}{ Water Quality Parameters } & Class I & Class II & Class III & Class IV & Class V \\
\hline \multirow{18}{*}{ Basic parameters } & $\mathrm{pH}$ (dimensionless) & & & $6-9$ & & \\
\hline & Dissolved oxygen $(\mathrm{DO}) \geq$ & Saturation rate $90 \%$ (or 7.5 ) & 6 & 5 & 3 & 2 \\
\hline & Permanganate index $\leq$ & 2 & 4 & 6 & 10 & 15 \\
\hline & Five-day biochemical oxygen demand (BOD) $\leq$ & 3 & 3 & 4 & 6 & 10 \\
\hline & $\mathrm{NH}_{3}-\mathrm{N} \leq$ & 0.15 & 0.5 & 1.0 & 1.5 & 2.0 \\
\hline & Total phosphorus (TP) & $\begin{array}{c}0.02 \\
\text { (lake/reservoir 0.01) }\end{array}$ & $\begin{array}{c}0.1 \\
\text { (lake/reservoir 0.025) }\end{array}$ & $\begin{array}{c}0.2 \\
\text { (lake/reservoir 0.05) }\end{array}$ & $\begin{array}{c}0.3 \\
\text { (lake/reservoir 0.1) }\end{array}$ & $\begin{array}{c}0.4 \\
\text { (lake/reservoir 0.4) } \\
\end{array}$ \\
\hline & $\mathrm{Cu} \leq$ & 0.01 & 1.0 & 1.0 & 1.0 & 1.0 \\
\hline & $\mathrm{Zn} \leq$ & 0.05 & 1.0 & 1.0 & 2.0 & 2.0 \\
\hline & Fluoride $\leq$ & 1.0 & 1.0 & 1.0 & 1.5 & 1.5 \\
\hline & $\mathrm{Se} \leq$ & 0.01 & 0.01 & 0.01 & 0.02 & 0.02 \\
\hline & As $\leq$ & 0.05 & 0.05 & 0.05 & 0.1 & 0.1 \\
\hline & $\mathrm{Hg} \leq$ & 0.00005 & 0.00005 & 0.0001 & 0.001 & 0.001 \\
\hline & $\mathrm{Cd} \leq$ & 0.001 & 0.005 & 0.005 & 0.005 & 0.01 \\
\hline & $\operatorname{Cr}($ hexavalent $) \leq$ & 0.01 & 0.05 & 0.05 & 0.05 & 0.1 \\
\hline & Cyanide $\leq$ & 0.005 & 0.05 & 0.2 & 0.2 & 0.2 \\
\hline & Volatile phenol $\leq$ & 0.002 & 0.002 & 0.005 & 0.01 & 0.1 \\
\hline & Anionic surface activity & 0.2 & 0.2 & 0.2 & 0.3 & 0.3 \\
\hline & Sulfide $\leq$ & 0.05 & 0.1 & 0.2 & 0.5 & 1.0 \\
\hline \multirow{5}{*}{$\begin{array}{l}\text { Supplement parameters by } \\
\text { water source area }\end{array}$} & Sulfate $\leq$ & & & 250 & & \\
\hline & Chloride $\leq$ & & & 250 & & \\
\hline & Nitrate nitrogen $\leq$ & & & 10 & & \\
\hline & $\mathrm{Fe} \leq$ & & & 0.3 & & \\
\hline & $\mathrm{Mn} \leq$ & & & 0.1 & & \\
\hline
\end{tabular}




\subsection{Procedures and Methods of Regionalization}

\subsubsection{General Thought on Regionalization}

It is required to both consider and implement the water pollution prevention and water resources protection in each district, county, and town, due to Xiaofu River across the towns and streets of several districts. Thus it is necessary to manage the township-level water functional zoning for the Xiaofu River trunk stream water area, which refines the districts and counties section in Zibo City Water Functional Zoning into villages, towns, and streets, adding supplementary division in the non-zoning part of the municipal division.

\subsubsection{Determination of Dominant Functions}

When a certain water functional area has multiple functions, it shall be classified as a drinking water source area if those involving living and drinking functions regardless of the amount of water taken, and the corresponding water quality standard should be determined. In addition, when the other four functions of industry, agriculture, fishery, and landscape entertainment overlap, the dominant function is determined by the amount of water intake, and the water quality standard of this functional area is the one with the highest water quality requirement. If there are multiple using functions currently existing in the water area, the dominant function is supposed to be determined, and its water quality standard should be controlled in terms of the peak water quality standard among the various user functions.

\subsubsection{Setting of Control Section}

Boundary sections of water functional zones should be located at clearly marked places or administrative junctions. Rivers across the town are supposed to be delimited as secondary functional zones regardless of whether the upstream and downstream water bodies have the same using functions. The water quality monitoring control sections in water functional zones should be located at the river reaches where the water quality of boundary sections is most likely to exceed the standard, which conforms to the basic requirements for water quantity and quality monitoring, combined with the existing monitoring sites as far as possible.

\subsubsection{Naming of Water Functional Zoning}

The name of the first-level zone is composed of river name, administrative region name, and water area function. The administrative region adopts district and township (street) administrative name, where the nature reserve retains its original name, and the names of source water and division water source area include the name of river and location, source water (source of water division), and the name of the protection zone.

The naming of the second-level zone is similar to that of the first-level zone, while the name of the place is set based on towns (streets). That with overlapping functions would be named by river and place, dominant function, and secondary function. According to the Water Functional Zone Division Standard (GB/T 50594-2010), the first-level functional zones mainly include the protection zone, reserve zone, development and utilization zone, and buffer zone. In contrast, the second-level functional zones have seven types: drinking water source zone, industrial water zone, agricultural water zone, fishery water zone, landscape water zone, transition zone, and sewage control zone.

\subsubsection{Procedures and Methods of Regionalization}

The water function zoning scope is the main stream of Xiaofu River, taking 2018 as the base year of the division. According to environmental protecting governance work and planning requirements, 2023 is determined as the planning level year, combined with social and economic development. 


\subsubsection{Setting of the Water Quality Objectives}

Based on the implementation plan for preventing and controlling water pollution in Zibo city and related management requirements, it is required to determine the overall goal of Xiaofu River water functional regionalization is that the whole river reaches the class $\mathrm{V}$ surface water requirements, thereinto COD and ammonia nitrogen as the main indicators of Xiaofu River wetland park reach the class III surface water standard requirement.

\subsection{Contamination Capacity Accounting Method}

\subsubsection{Hydrological Parameters and Statistics}

The total length of the main stream of Xiaofu River in Zibo City is $85.7 \mathrm{~km}$, which starts from Shentou Springs in Boshan District northward to Yuanjia Bridge in Zhoucun District, and enters Xiaoqing River through Huantai County. There is a river hydrological station located at Mashang village in the main stream. The annual hydrological and statistical data of Mashang station were adopted to calculate the pollution capacity.

When calculating the sewage capacity, the design flow of the calculated section is usually taken as the main design parameter. Under current conditions, the driest average monthly flow in the last 10 years or the average monthly average flow $(90 \%$ guarantee rate) is generally used as the design flow. For some rivers in northern China, the design guarantee rate can be appropriately adjusted according to the actual situation, or the dry water flow in the typical year of normal and drought period can be selected as the design flow.

\subsubsection{Water Quality Model}

Under the designing hydrological conditions, Xiaofu River belongs to a small and medium-sized river with a shallow channel and less width to depth ratio. Pollutants can be evenly mixed in the section soon due to the straight stream and its small flow rate. Pollutants mainly migrate vertically along the river, and the transverse concentration of pollutants varies little. Therefore the sewage capacity can be calculated using a onedimensional model. The model formula is as follows:

$$
C_{x}=C_{0} \exp \left(-K \frac{x}{u}\right) .
$$

where $C_{0}$ is the initial pollutant concentration, $C_{x}$ is the pollutant concentration after flowing through an $x$ distance, $x$ is the longitudinal distance of the river section, $u$ is the average flow rate of the river section under the design flow, and $K$ is the comprehensive attenuation coefficient of pollutants. The pollutant attenuation coefficient exactly reflects the change in river water pollution [22]. It is one of the important parameters of establishing a water quality model and calculating water environmental capacity [23].

\subsubsection{Water Quality Target Values and Pollution Factors}

According to the Supplementary Technical Rules for the Protection of Surface Water Resources in the National Comprehensive Water Resources Planning [24], the principle of water functional zones division and pollution control is that no matter how many contaminants the last functional zone receive, the water quality of the last functional zone must meet the water quality target requirements when entering the next functional zone. If the calculation unit is a non-source section, the water quality target of the previous functional area can be adopted as the water quality concentration of the upper section. Therefore, the water quality objectives of each functional area shall determine the corresponding water quality targets according to the water functional zones designated in this division.

According to the specific requirements of the total pollutant discharge control plan of major pollutants of Shandong Province, and taking the river water quality into consideration, $\mathrm{COD}$ and $\mathrm{NH}_{3}-\mathrm{N}$ are both selected as the calculated pollution factors for the pollution capacity of the water areas. 


\subsubsection{Designed Flow and Velocity of the Functional Zoning}

The river flow rate of functional areas is calculated according to Empirical Relation between Flow and Other Hydrological Parameters in Shandong Province. The empirical relationship between flow rate and other hydrologic parameters is shown in the following formula:

$$
\begin{gathered}
u=\alpha Q^{\beta} \\
h=\gamma Q^{\sigma} \\
A=\frac{1}{\alpha} Q^{1-\beta} \\
B=\frac{1}{\alpha \gamma} Q^{1-\beta-\sigma}
\end{gathered}
$$

where $Q$ is the flow, $u$ is the mean flow rate, $A$ is the cross-sectional area, $B$ is the width of the river surface, $\alpha, \beta, \gamma, \sigma$ are all undetermined coefficients.

When the measured river flow result during the dry period is known, there are several groups $Q, u$, and $h$, and the parameter $\alpha, \beta, \gamma$, and $\sigma$ were estimated by regression analysis.

\subsubsection{Comprehensive Degradation Coefficient of Pollutants}

The site measurement may not be sure to reproduce the hydrological and water quality design conditions of water pollution capacity calculation. Moreover, determining the pollutant degradation coefficient of each functional area is more limited; the COD degradation coefficient $K_{C}$ of Xiaofu River was determined as 0.30 and the ammonia nitrogen degradation factor $K_{N}$ as 0.28 , according to the empirical value of River Water Environment Capacity Research in Shandong Province and combined with the dynamic river condition, landform type, and water quality target.

\subsubsection{Water Quality Model and Parameters}

With negligible non-point sources, the selected parameters mentioned above were brought into the following formula:

$$
W=31.536\left(C_{S} e^{K \frac{L}{86.4 \times 2 \times u}}-C_{0} e^{-K \frac{L}{86.4 \times 2 \times u}}\right) \times Q
$$

where $W$ is the pollution capacity of functional zoning, $C_{0}$ is the pollutant concentration in the starting section of functional zoning, $C_{S}$ is the water quality target concentration of the functional zoning, $K$ is the comprehensive degradation coefficient of pollutants, $Q$ is the flow of functional zoning, $L$ is the length of the functional zoning, and $u$ is the flow rate under the design flow value.

\section{Results and Analysis}

\subsection{Xiaofu River Municipal Functional Zoning Situation}

According to Water Function Zoning of Shandong Province, the first-level functional zone of Xiaofu River is also defined as the Xiaofu River Zibo development and utilization area, and the second-level functional zone is divided into Xiaofu River Zibo drinking water source area, Fanyanghe River Zibo drinking water source area, and Xiaofu River Zibo industrial water area. On the basis of provincial zoning, 2012 Zibo City Water Functional Regionalization divides Xiaofu River Zibo development and utilization area that refers to the river length of $109 \mathrm{~km}$ from the river fountainhead to Xiaoqing River estuary into six secondary water function areas, in which one drinking water source area and five agricultural water area are classified.

\subsection{Water Quality Current Situation of Xiaofu River Truck Stream}

According to Surface Water Environmental Quality Standard (GB3838-2002) and water quality purpose of functional zones, whole indexes of Xiaofu River main stream were 
analyzed to reach the standard and evaluated, and the evaluation results are shown in Figure 2 and Table 2.

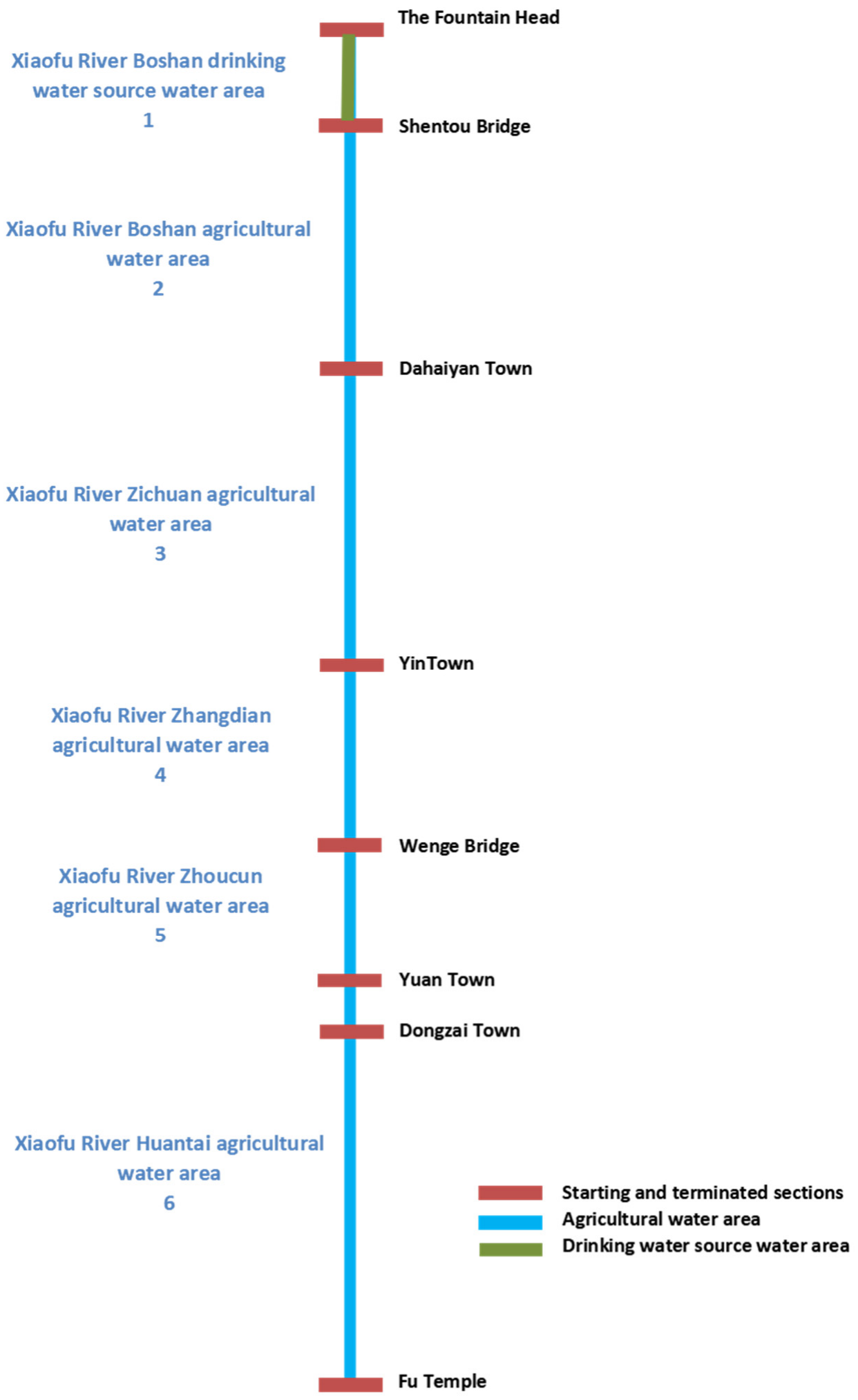

Figure 2. Municipal water functional zones' name and critical section. 
Table 2. Water quality and evaluation results of Xiaofu River municipal water functional zones.

\begin{tabular}{cccccc}
\hline No. & $\begin{array}{c}\text { Monitoring } \\
\text { Section }\end{array}$ & Length $(\mathbf{k m})$ & COD $(\mathbf{m g} / \mathbf{L})$ & $\begin{array}{c}\mathbf{N H}_{3}-\mathbf{N} \\
(\mathbf{m g} / \mathbf{L})\end{array}$ & $\begin{array}{c}\text { Double Indexes } \\
\text { Evaluation }\end{array}$ \\
\hline 1 & Linli Lake & 8 & 6.0 & 0.26 & Class III \\
2 & $\begin{array}{c}\text { Dahaiyan } \\
\text { Town }\end{array}$ & 19 & 22.6 & 3.60 & Class V \\
3 & Yin Town & 24 & 28.0 & 3.72 & Class IV \\
4 & Yiji Town & 16 & 28.3 & 3.22 & Class IV \\
5 & Yuan Town & 13 & 31.2 & 2.70 & Class V \\
6 & Fu Temple & 29 & 37.6 & 1.38 & Class V \\
\hline
\end{tabular}

\subsection{Zoning Scheme}

According to the water functional zoning standard and the national technical outline, the water functional zoning of Xiaofu River adopts a two-level system, namely first-level and second-level water function zoning. Through data collection, field investigation, analysis and evaluation, the main stream of Xiaofu River in Zibo City Water Functional Zoning is subdivided into towns and streets, and the undivided part in Zibo City Water Functional Zoning is supplemented.

\subsubsection{First-Level Water Functional Zoning Scheme}

The main stream of Xiaofu River originates from Shentou spring group in Boshan District, which runs north through Boshan urban area, passes Zichuan, Zhangdian, Zhoucun, Zouping and then enters into Huantai, lastly exits from Huantai and enters into Xiaoqing River.

According to the protection and management regulations of Tai River reservoir drinking water source and Zibo City Water Functional Zoning, and combined with the actual local situation and current function, Xiaofu River was divided into five water functional zones, following with the principle of tributary subordinating the main stream. These water functional zones are Xiaofu River Boshan development and utilization zone, Xiaofu River Zichuan development and utilization zone, Xiaofu River Zhangdian development and utilization zone, Xiaofu River Zhoucun development and utilization zone, and Xiaofu River Huantai development and utilization zone, respectively. The specific results are shown both in Figure 3 and Table 3.

\subsubsection{Second-Level Water Functional Zoning Scheme}

The Boshan section of Xiaofu River, from Shentou Bridge to Dahaiyan Village, flows through three subdistricts: Chengxi Street, Chengdong Street, and Baita Town. According to the municipal water function zonization, it is divided into the Chengxi and Chengdong landscape water area and the Baita landscape water area, all of which are subject to the Class V of Surface Water Environmental Quality Standard.

Xiaofu River within the territory of Zichuan District flows through Kunlun Town, Jiangjun Street, Banyang Street, Songling Street, Development Zone, and Shuangyang Town. According to actual local conditions, this section of the Xiaofu River is divided into Kunlun landscape river water area, Jiangjun Street landscape water area, Banyang Street landscape water area, Songling Street landscape water area, Development Zone landscape water area, and Shuangyang landscape water area, all of which are subject to the Class $\mathrm{V}$ standard as well.

Xiaofu River passes through Zichuan and enters into Zhangdian District at Huangjia Village of Fujia Town, and then exits into Zhoucun District at Beijiao Town. According to municipal water function zonalization, it is divided into Fujia landscape water area, Mashang landscape water area, and Beijiao landscape water area, all of which are complied with the Class V standard as well.

Xiaofu River runs through Maqiao Town, Tianzhuang Town, and Jingjia Town in Huantai County. According to the municipal water function zoning, the three towns are 
divided into Maqiao agricultural water area, Tianzhuang agricultural water area, and Jingjia agricultural water area, and the Class V of Surface Water Environmental Quality Standards are all implemented.

In summary, in accordance with the principle that tributaries are subordinate to the main stream and the lower level zoning is subordinate to the higher level zoning, the water function zoning of the main stream of Xiaofu River is divided into 14 secondary functional zones in this water function zoning division, according to the municipal zoning and current functions as well as the actual local situations. The specific results are shown in Figures 4 and 5 , respectively.

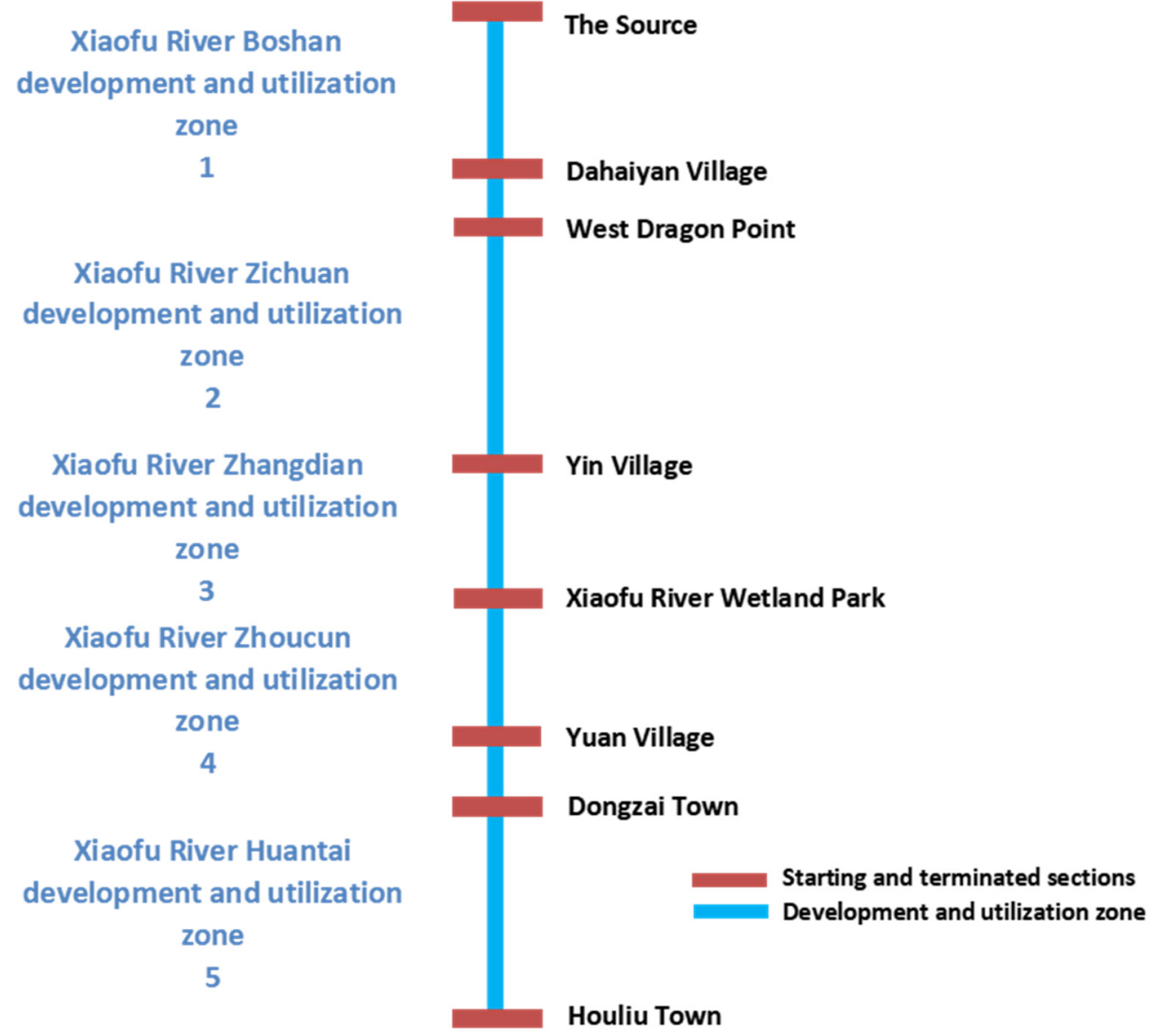

Figure 3. First-level water functional zones' information.

Table 3. Results of Xiaofu River first-level water functional zoning.

\begin{tabular}{cccccccc}
\hline No. & Catchment & Basin & River & $\begin{array}{c}\text { Length } \\
\mathbf{( k m )}\end{array}$ & $\begin{array}{c}\text { Current Water } \\
\text { Quality }\end{array}$ & $\begin{array}{c}\text { Targeted } \\
\text { Water Quality }\end{array}$ & Zoning Basis \\
\hline 1 & Huai River & Xiaoqing River & Xiaofu River & 11.7 & IV & III-V & City-level zoning \\
2 & Huai River & Xiaoqing River & Xiaofu River & 26.3 & V & V & City-level zoning \\
3 & Huai River & Xiaoqing River & Xiaofu River & Left bank: 2.6 & V & V & City-level zoning \\
4 & Huai River & Xiaoqing River & Xiaofu River & 11.6 & V & V & City-level zoning \\
5 & Huai River & Xiaoqing River & Xiaofu River & 24.8 & V & V & City-level zoning \\
\hline
\end{tabular}


Chengxi and Chengdong landscape water area 1, Length: $4.7 \mathrm{~km}$

Baita landscape water area

2, Length: $7.0 \mathrm{~km}$

Kunlun landscape water area

3, Length: $5.5 \mathrm{~km}$

Jiangjun Street landscape water area

4, Length: $5.9 \mathrm{~km}$

Banyang Street landscape water area

5, Length: $1.1 \mathrm{~km}$

Songling Street landscape water area

6, Length: $2.5 \mathrm{~km}$

Development Zone landscape water area

7, Length: $3.6 \mathrm{~km}$

Shuangyang landscape water area

8, Length: $7.7 \mathrm{~km}$

Fujia landscape water area

9, Length: L $2.6 \mathrm{~km}$ R $7.4 \mathrm{~km}$

Mashang landscape water area

10, Length: R $1.3 \mathrm{~km}$

Beijiao landscape water area

11, Length: $11.6 \mathrm{~km}$

Maqiao agricultural water area

12, Length: $10.5 \mathrm{~km}$

Tianzhuang agricultural water area

13, Length: $3.2 \mathrm{~km}$

Jingjia agricultural water area

14, Length: $11.1 \mathrm{~km}$

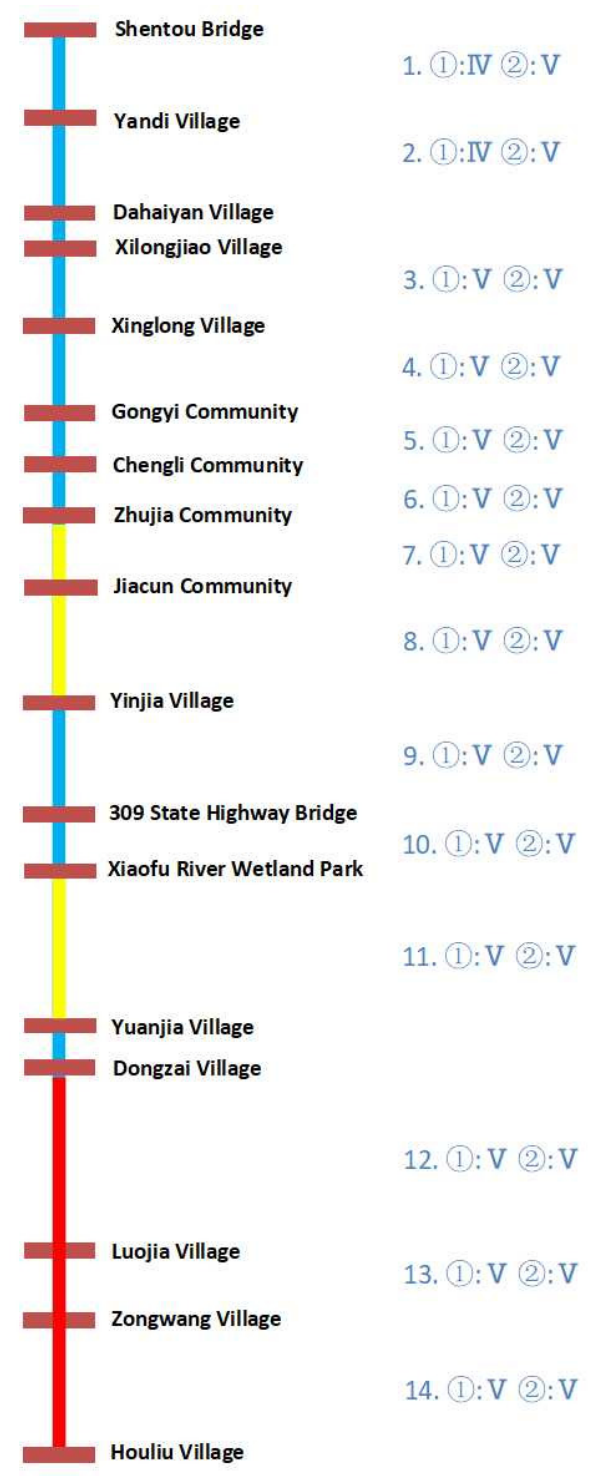

Figure 4. Second-level water functional zones' information. 


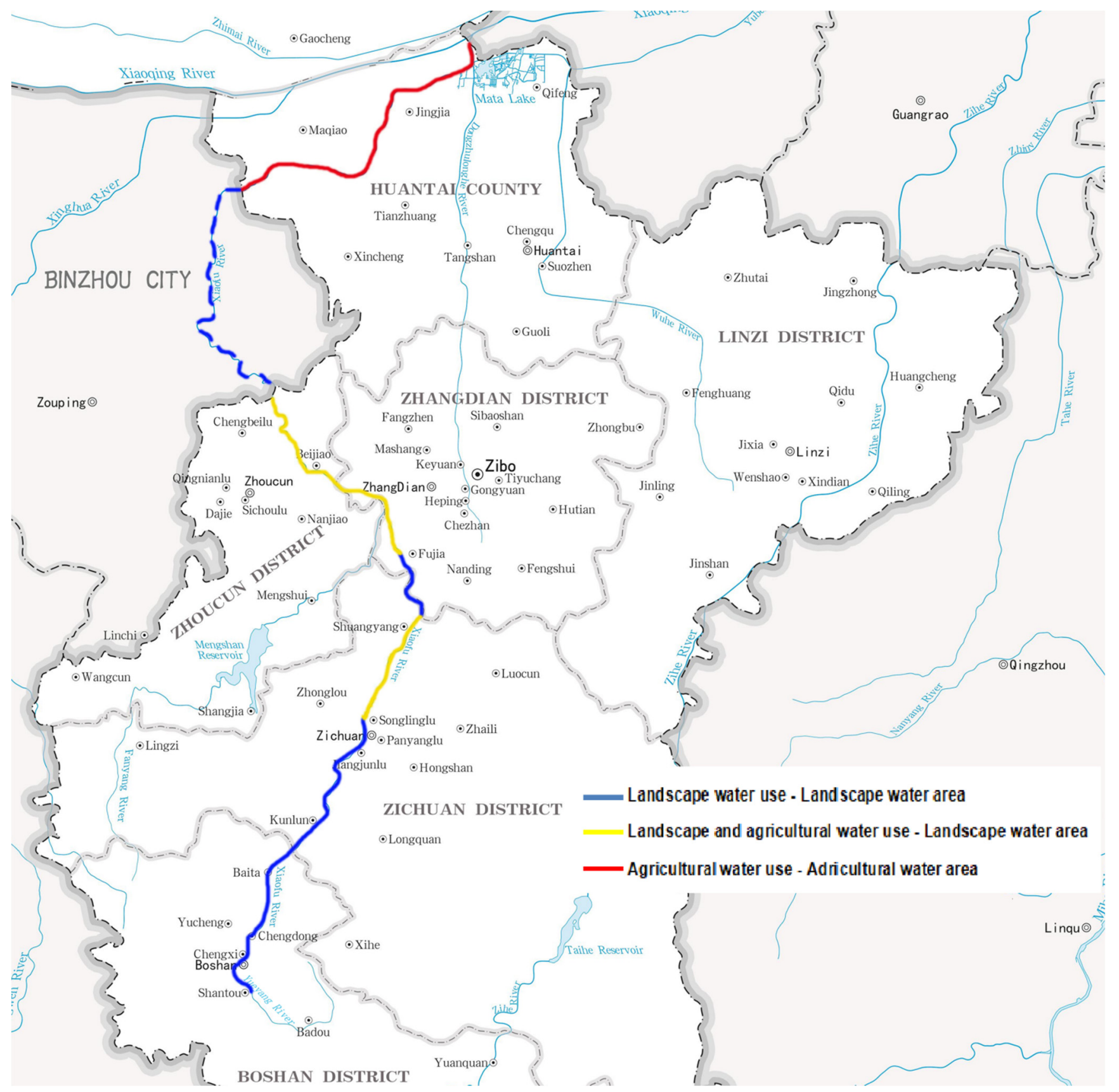

Figure 5. Second-level water functional zoning scheme.

\subsection{Contamination Capacity Accounting Results}

Based on the given hydrological factors such as river flow, velocity, length of reach, comprehensive attenuation coefficient, and pollutant concentration at starting and terminated sections [25], the annual contamination capacity accounting value of each functional area was calculated and shown in Table 4 . 
Table 4. Contamination capacity accounting results of each functional zoning at country level in the Trunk Stream of Xiaofu River.

\begin{tabular}{|c|c|c|c|c|c|c|c|}
\hline \multirow{2}{*}{ No. } & \multirow{2}{*}{$\begin{array}{c}\text { Second-Level Water Functional Zones' } \\
\text { Name }\end{array}$} & \multirow{2}{*}{ Basin } & \multirow{2}{*}{ River } & \multirow{2}{*}{$\begin{array}{l}\text { Length } \\
(\mathbf{k m})\end{array}$} & \multirow{2}{*}{$\begin{array}{c}\text { Targeted } \\
\text { Water } \\
\text { Quality }\end{array}$} & \multicolumn{2}{|c|}{$\begin{array}{c}\text { Annual Contamination } \\
\text { Capacity (kg) }\end{array}$} \\
\hline & & & & & & COD & $\mathrm{NH}_{3}-\mathrm{N}$ \\
\hline 1 & $\begin{array}{l}\text { Chengxi } \\
\text { and Chengdong landscape water area }\end{array}$ & Xiaoqing River & Xiaofu River & 4.7 & $\mathrm{~V}$ & $9.28 \times 10^{5}$ & $4.69 \times 10^{4}$ \\
\hline 2 & Baita landscape water area & Xiaoqing River & Xiaofu River & 7.0 & $\mathrm{~V}$ & $1.94 \times 10^{5}$ & $9.04 \times 10^{3}$ \\
\hline 3 & Kunlun landscape water area & Xiaoqing River & Xiaofu River & 5.5 & $\mathrm{~V}$ & $1.52 \times 10^{5}$ & $7.09 \times 10^{3}$ \\
\hline 4 & Jiangjun Street landscape water area & Xiaoqing River & Xiaofu River & 5.9 & $\mathrm{~V}$ & $1.63 \times 10^{5}$ & $7.62 \times 10^{3}$ \\
\hline 5 & Banyang Street landscape water area & Xiaoqing River & Xiaofu River & 1.1 & $\mathrm{~V}$ & $3.04 \times 10^{4}$ & $1.42 \times 10^{3}$ \\
\hline 6 & Songling Street landscape water area & Xiaoqing River & Xiaofu River & 2.5 & $\mathrm{~V}$ & $6.91 \times 10^{4}$ & $3.23 \times 10^{3}$ \\
\hline 7 & Development Zone landscape water area & Xiaoqing River & Xiaofu River & 3.6 & $\mathrm{~V}$ & $9.96 \times 10^{4}$ & $4.65 \times 10^{3}$ \\
\hline 8 & Shuangyang landscape water area & Xiaoqing River & Xiaofu River & 7.7 & $\mathrm{~V}$ & $2.13 \times 10^{5}$ & $9.94 \times 10^{3}$ \\
\hline 9 & Fujia landscape water area & Xiaoqing River & Xiaofu River & $\begin{array}{l}\text { Left bank: } 2.6 \\
\text { Right bank: } 7.4\end{array}$ & $\mathrm{~V}$ & $\begin{array}{l}7.19 \times 10^{4} \\
1.02 \times 10^{5}\end{array}$ & $\begin{array}{l}3.36 \times 10^{3} \\
9.55 \times 10^{3}\end{array}$ \\
\hline 10 & Mashang landscape water area & Xiaoqing River & Xiaofu River & Right bank: 1.3 & $\mathrm{~V}$ & $3.59 \times 10^{4}$ & $1.68 \times 10^{3}$ \\
\hline 11 & Beijiao landscape water area & Xiaoqing River & Xiaofu River & 11.6 & $\mathrm{~V}$ & $3.21 \times 10^{5}$ & $1.49 \times 10^{4}$ \\
\hline 12 & Maqiao agricultural water area & Xiaoqing River & Xiaofu River & 10.5 & $\mathrm{~V}$ & $2.91 \times 10^{5}$ & $1.36 \times 10^{4}$ \\
\hline 13 & Tianzhuang agricultural water area & Xiaoqing River & Xiaofu River & 3.2 & $\mathrm{~V}$ & $8.85 \times 10^{4}$ & $4.13 \times 10^{3}$ \\
\hline 14 & Jingjia agricultural water area & Xiaoqing River & Xiaofu River & 11.1 & $\mathrm{~V}$ & $3.07 \times 10^{5}$ & $1.43 \times 10^{4}$ \\
\hline 15 & Total & Xiaoqing River & Xiaofu River & 85.7 & $\mathrm{~V}$ & $3.07 \times 10^{6}$ & $1.51 \times 10^{5}$ \\
\hline
\end{tabular}

As indicated in Table 4, the total annual pollution capacity of the 14 county-level water functional areas designated by the main stream of the Xiaofu River is COD of $3.07 \times 10^{6} \mathrm{~kg}$, $\mathrm{NH}_{3}-\mathrm{N}$ of $1.51 \times 10^{5} \mathrm{~kg}$. The total amount of annual contamination capacity is the basis for formulating the red line index of pollution restriction in each water functional area. The total amount of pollutants annually discharged into each functional area must be strictly controlled to ensure the realization of the river water environment management objectives.

\subsection{Current Pollutant Discharge and Reduction Analysis}

In recent years, the water environment has been constantly improved in Zibo City, and the comprehensive control plan involving treatment and protection of the Xiaofu River basin has been implemented overall. In addition to retaining the sewage outlets of centralized urban sewage treatment plants in all districts and counties, other industrial and domestic sewage outlets scattered into the river were accurately blocked, and non-point sources in the river basin were also treated by unified and centralized rectification.

According to the treatment scale and water quality of the urban sewage treatment plants in the upper reaches of the main stream of Xiaofu River, the current sewage discharge was calculated, and the statistical results are shown in Table 5.

As indicated in Table 5, the total water output from the sewage treatment plant discharged into the upper reaches of the main stream of Xiaofu River is $223,000 \mathrm{~m}^{3} / \mathrm{d}$. According to the requirements of environmental protection emission standards, the total amount of annual pollutant discharge shall be converted to be COD of $2.77 \times 10^{6} \mathrm{~kg}$, $\mathrm{NH}_{3}-\mathrm{N}$ of $1.39 \times 10^{5} \mathrm{~kg}$, both of which are lower than the total annual contamination capacity of the river channel. It states clearly that the current sewage discharge can basically meet the requirements of sewage pollution capacity, which further shows that the upgrading of sewage treatment plants and comprehensive water environment treatment has been effective in recent years. 
Table 5. Annual contamination capacity accounting results of each functional zoning at country level in the Trunk Stream of Xiaofu River.

\begin{tabular}{|c|c|c|c|c|c|c|}
\hline \multirow{2}{*}{ No. } & \multirow{2}{*}{ Name of Sewage Plant } & \multirow{2}{*}{$\begin{array}{l}\text { Effluent } \\
\left(10^{4} \mathrm{~m}^{3} / \mathrm{d}\right)\end{array}$} & \multicolumn{2}{|c|}{$\begin{array}{l}\text { Concentration of } \\
\text { Emission }(\mathrm{mg} / \mathrm{L})\end{array}$} & \multicolumn{2}{|c|}{$\begin{array}{c}\text { Current Pollutant } \\
\text { Annual Discharge (kg) }\end{array}$} \\
\hline & & & COD & $\mathrm{NH}_{3}-\mathrm{N}$ & COD & $\mathrm{NH}_{3}-\mathrm{N}$ \\
\hline 1 & Huanke Sewage Treatment Plant & 7.5 & 30.0 & 1.5 & $8.21 \times 10^{5}$ & $4.11 \times 10^{4}$ \\
\hline 2 & Baita Sewage Treatment Plant & 1.5 & 30.0 & 1.5 & $1.64 \times 10^{5}$ & $8.21 \times 10^{3}$ \\
\hline 3 & Yueyang Sewage Treatment Plant & 0.3 & 30.0 & 1.5 & $3.29 \times 10^{4}$ & $1.64 \times 10^{3}$ \\
\hline 4 & Bashan Sewage Treatment Plant & 1.0 & 30.0 & 1.5 & $1.10 \times 10^{5}$ & $5.47 \times 10^{3}$ \\
\hline 5 & $\begin{array}{c}\text { Gezhouba Group Water Zichuan } \\
\text { Water Plant }\end{array}$ & 3.0 & 30.0 & 1.5 & $3.29 \times 10^{5}$ & $1.64 \times 10^{4}$ \\
\hline 6 & Limin sewage purification plant & 6.0 & 40.0 & 2.0 & $8.76 \times 10^{5}$ & $4.38 \times 10^{4}$ \\
\hline 7 & Watt Sewage Treatment Plant & 3.0 & 40.0 & 2.0 & $4.38 \times 10^{5}$ & $2.19 \times 10^{4}$ \\
\hline 8 & Total & 22.3 & $30.0-40.0$ & $1.5-2.0$ & $2.77 \times 10^{6}$ & $1.39 \times 10^{5}$ \\
\hline
\end{tabular}

\section{Conclusions}

Xiaofu River is the typical main river in the Zibo area; thus, its water quality protection, pollution prevention, and control are of great significance to the local water environment and ecological construction. The water function zoning at the county-level for the mainstream of Xiaofu River is divided into 14 water function zones that include 11 landscape water areas and 3 agricultural water areas, which not only realizes the full coverage of the county-level water function zones of the mainstream of Xiaofu River but also is an effective supplement to the district level river and lake chief system. According to the water quality model calculation, the total annual pollutant carrying capacity COD and $\mathrm{NH}_{3}-\mathrm{N}$ are $3.07 \times 10^{6} \mathrm{~kg}$ and $150.6 \mathrm{t} / \mathrm{a}$, respectively, in 14 county-level water function areas, which are the basis for the formulation of the limit red line index of pollutant carrying capacity in each water function area. After the investigation and statistics, the total annual amount of $\mathrm{COD}$ and $\mathrm{NH}_{3}-\mathrm{N}$ discharged into the mainstream and upstream of Xiaofu River separately are $2.77 \times 10^{6} \mathrm{~kg}$ and $1.39 \times 10^{5} \mathrm{~kg}$, respectively, namely the current sewage discharge can basically meet the requirements of carrying capacity. From the perspective of future prospects, the total amount of pollutants discharged into each functional area should be further controlled and reduced, and the self-purification capacity of rivers should be restored through reconstruction of the river ecosystem so as to ensure the realization of river environment management objectives.

Author Contributions: Conceptualization, J.D. and S.D.; methodology, J.L.; validation, F.W., X.S. and J.L.; formal analysis, S.D.; investigation, F.W.; resources, S.D.; data curation, X.S.; writing—original draft preparation, S.D.; writing—review and editing, S.D.; supervision, J.L.; project administration, J.D. All authors have read and agreed to the published version of the manuscript.

Funding: This work was supported by the Natural Science Foundation of Shandong Province, China [Grant Number ZR2020MB123] and Zibo City Integration Development Project [Grant Number 2019ZBXC392].

Data Availability Statement: The data supporting reported results in this article can be found in the Zibo Ecological Environment Information System.

Acknowledgments: The authors wish to express their thanks to Zibo Jinxuan Resources and Environmental Technology Development Co. Ltd. for their sincere help during this work.

Conflicts of Interest: The authors declare no conflict of interest. 


\section{References}

1. Zhang, C.; Xie, G.; Cao, S.; Leng, Y.; Yu, X. The Distribution Patterns of China's County Ecological Function. Resour. Sci. 2012, 34, $1636-1646$.

2. $\mathrm{Xu}, \mathrm{K} . ;$ Wang, J.; Wang, J.; Wang, X.; Chi, Y.; Zhang, X. Environmental function zoning for spatially differentiated environmental policies in China. J. Environ. Manag. 2020, 255, 27-36. [CrossRef] [PubMed]

3. Fischer, S.; Thatje, S. Temperature effects on life-history traits cause challenges to the management of brachyuran crab fisheries in the Humboldt Current: A review. Fish. Res. 2018, 183, 461-468. [CrossRef]

4. Liu, Y.; Li, T.; Zhao, W.; Wang, S.; Fu, B. Landscape functional zoning at a county level based on ecosystem services bundle: Methods comparison and management indication. J. Environ. Manag. 2019, 249, 109-315. [CrossRef] [PubMed]

5. Barral, M.P.; Oscar, M.N. Land-use planning based on ecosystem service assessment: A case study in the Southeast Pampas of Argentina. Agric. Ecosyst. Environ. 2012, 154, 34-43. [CrossRef]

6. Jiang, H.Q.; Liu, N.L.; Hu, X. Progress in research and practice of the ecological environmental space control system in China. Environ. Prot. 2019, 47, 32-36.

7. Wang, J.; Huang, J.; Zhang, L.; Huang, Q.; Rozelle, S. Water governance and water use efficiency: The five principles of WUA management and performance in China. J. Am. Water Resour. Assoc. 2010, 46, 665-685. [CrossRef]

8. Jiang, W. Can Environmental Protection in Ecological Functional Zones Break Free from the Constraints of Focusing Just on Economic Benefits?-A Case Study of the Plateau Ecological Zone's Tiamitcheen. Chin. J. Urban Environ. Stud. 2018, 6, 185-189. [CrossRef]

9. Lu, L.Z.; Mou, Y.M.; Yu, H.Y.; Hang, D.W.; Shen, H.; Huang, Y.L. Environmental function zoning at regional scale: A case study in Pinghu, China. Fourth Int. Conf. Agro-Geoinform. 2015, 7248086, 203-207.

10. Gao, P.; Song, Y.S.; Yang, C. Water function zoning and water environment capacity analysis on surface water in jiamusi urban area. Procedia Eng. 2012, 28, 458-463.

11. Bychkov, I.V.; Gagarinova, O.V.; Orlova, I.I.; Bogdanov, V.N. Water protection zoning as an instrument of preservation for Lake Baikal. Water 2018, 10, 1474. [CrossRef]

12. Jafar, N.; Ahmad, N.; Ehsan, N.; Morteza, A. GIS-based agro-ecological zoning for crop suitability using fuzzy inference system in semi-arid regions. Ecol. Indic. 2020, 117, 106-115.

13. Yang, H.R. Water Function Area System in China and its Corresponding Classification. China Water Resour. 2001, $12,40-45$.

14. Stanislav, V.; Dubrova, I.; Podlipskiy, I.; Vitaliy, V.; Kurilenko, W.S. Functional city zoning. Environmental assessment of eco-geological substance migration flows. Environ. Pollut. 2015, 197, 165-172.

15. Shi, X.X.; Yang, Q.; Wang, X.H.; Zhang, J.Y. Thoughts on top-level design of water resources protection in China. China Water Resour. 2017, 19, 12-19.

16. Zhang, X.D.; Mu, J.B. Study on Water Environmental Capacity of Rivers in Shandong Province, 1st ed.; Shandong University Publisher: Jinan, China, 2007; pp. 61-77.

17. Meng, Q.; Liu, M.; Liu, A. Spatial Variation and Contamination Assessment of Heavy Metals in Surface Sediments of Xiaofu River. Health Environ. Res. 2013, 6, 18-25.

18. Wu, Y.G.; Sun, Z.L.; Zhang, Z. Characters and Formation Reasons of Sulfate Contamination in Pore Water of Xiao Fu River Basin in Zibo City. Environ. Pollut. Control 2000, 22, 36-39.

19. Liu, A.; Wang, H.; Pan, J.; Li, M. Relationship between heavy metals speciation and microbial community structure in surface sediments of Xiaofu River. China Environ. Sci. 2010, 30, 1103-1109.

20. Wang, H.R.; Zhu, G.R.; Wang, X.Q. Study Oil Exploitation of Groundwater at Headstream Area of Xiaofu River. Geol. J. China Univ. 2001, 7, 237.

21. Xu, K.P.; Chi, Y.Y.; Lu, J.; Wang, J.N. Study on the Progress and Outlook of Environmental Function Zoning. Environ. Prot. 2017, $45,53-57$.

22. Kapoor, R.K.; Gupta, V.K. A pollution attenuation coefficient concept for optimization of green belt. Atmos. Environ. 1984, 18, 1107-1113. [CrossRef]

23. Zhu, X.J.; Shen, W.B.; Gao, K.; Liu, J.S. Study on the integrated attenuation coefficient of $\mathrm{NH}_{3}-\mathrm{N}$ in the sectors of main stream of Songhua River in Jilin Province. Sci. Technol. Eng. 2013, 13, 2758-2773.

24. Ministry of Water Resources. Supplementary Technical Rules for the Protection of Surface Water Resources in the Comprehensive National Water Resources Plan, 1st ed.; Ministry of Water Resources: Beijing, China, 2003; pp. 30-34.

25. Uluatam, S.S. Calibration of modqual for karasu river. Water Res. 1993, 27, 943-948. [CrossRef] 